\title{
The atypical antipsychotic clozapine impairs insulin secretion by inhibiting glucose metabolism and distal steps in rat pancreatic islets
}

\author{
N. Sasaki • M. Iwase $\cdot$ Y. Uchizono $\cdot$ U. Nakamura • \\ H. Imoto • S. Abe $\cdot$ M. Iida
}

Received: 20 June 2006 / Accepted: 8 August 2006 / Published online: 27 October 2006

(C) Springer-Verlag 2006

\begin{abstract}
Aims/hypothesis Diabetogenic effects of some atypical antipsychotic drugs have been reported, although the mechanisms are not fully understood. We investigated the long-term effects of culturing isolated rat pancreatic islets with atypical antipsychotic clozapine.

Methods Glucose- and non-glucose-stimulated insulin secretion, glucose metabolism and intracellular $\mathrm{Ca}^{2+}$ concentration $\left(\left[\mathrm{Ca}^{2+}\right]_{\mathrm{i}}\right)$ were measured in islets cultured with or without clozapine.

Results Although acute incubation or 3-day culture with clozapine did not affect glucose-stimulated insulin secretion, clozapine suppressed glucose-stimulated insulin secretion by $53.2 \%$ at $1.0 \mu \mathrm{mol} / 1$ (therapeutic concentration) after 7 days of culture. Islet glucose oxidation and $\left[\mathrm{Ca}^{2+}\right]_{\mathrm{i}}$ elevation by high glucose were not affected after 3 days of culture, but clozapine significantly inhibited islet glucose oxidation, ATP production, and $\left[\mathrm{Ca}^{2+}\right]_{\mathrm{i}}$ elevation by high glucose after 7 days of culture. Moreover, 7 days of culture with clozapine inhibited insulin secretion stimulated by: (1) membrane depolarisation induced by high $\mathrm{K}^{+}$; (2) protein kinase $\mathrm{C}$ activation; and (3) mastoparan at 16.7 $\mathrm{mmol} / \mathrm{l}$ glucose under stringent $\mathrm{Ca}^{2+}$-free conditions. Elevation of $\left[\mathrm{Ca}^{2+}\right]_{\mathrm{i}}$ by high $\mathrm{K}^{+}$-induced membrane depolarisation was similar in control and clozapine-treated islets. Clozapine, a muscarinic blocker, acutely inhibited carbachol-induced insulin secretion, as did atropine, whereas after 7 days of culture atropine did not have the
\end{abstract}

N. Sasaki $\cdot$ M. Iwase $(\triangle) \cdot$ Y. Uchizono $\cdot$ U. Nakamura $\cdot$

$\mathrm{H}$. Imoto $\cdot \mathrm{S}$. Abe $\cdot$ M. Iida

Department of Medicine and Clinical Science,

Graduate School of Medical Sciences, Kyushu University,

Maidashi 3-1-1, Higashi-ku,

Fukuoka 812-8582, Japan

e-mail: iwase@intmed2.med.kyushu-u.ac.jp inhibitory effect shown by clozapine after 7 days. The impairment of glucose-stimulated insulin secretion recovered 3 days after the removal of clozapine treatment.

Conclusions/interpretation The present study demonstrated that the atypical antipsychotic drug clozapine directly impaired insulin secretion via multiple sites including glucose metabolism and the distal step in insulin exocytosis in a long-term culture condition. These mechanisms may be involved in the form of diabetes mellitus associated with atypical antipsychotic drugs.

Keywords Atypical antipsychotic drugs · Carbachol .

Clozapine · Drug-induced diabetes mellitus .

Glucose metabolism · Glucose oxidation · Insulin secretion .

Mastoparan $\cdot$ Pancreatic islets · Protein kinase C

\author{
Abbreviations \\ $\left[\mathrm{Ca}^{2+}\right]_{\mathrm{i}}$ intracellular $\mathrm{Ca}^{2+}$ concentration \\ PKC protein kinase $\mathrm{C}$ \\ TCA tricarboxylic acid \\ TPA 12-O-tetradecanoylphorbol-13-acetate
}

\section{Introduction}

Since the introduction of clozapine into clinical practice in the 1960s, atypical antipsychotic drugs have been widely used for the treatment of schizophrenia [1]. Pharmacologically, conventional antipsychotic drugs are high-affinity antagonists of dopamine $D_{2}$ receptors, while atypical antipsychotic drugs have lower affinity for dopamine $D_{2}$ receptors and greater affinity for other receptors including serotonin [1]. This pharmacological difference causes fewer instances of parkinsonian syndrome and tardive dyskinesia 
in patients treated with atypical antipsychotics. In addition, clozapine has been reported to be more effective than conventional antipsychotic drugs in reducing symptoms of patients with both treatment-resistant and non-resistant schizophrenia [2], suicide prevention [3], as well as remission of heavy cigarette smoking [4]. However, since the report of fatal agranulocytosis in patients treated with clozapine in 1975 [5], the use of clozapine has been limited only to patients with refractory schizophrenia.

Type 2 diabetes mellitus is frequently diagnosed in patients with schizophrenia [6]. Obesity, physical inactivity and cigarette smoking may be risk factors for the development of diabetes mellitus in these patients [6]. However, a case of diabetic ketoacidosis associated with clozapine use was reported in 1994 [7], and since then many case reports of new-onset diabetes mellitus have been published [8-10]. According to the Food and Drug Administration MedWatch surveillance system, the affected patients were relatively young (mean 40 years), most developed diabetes mellitus within 6 months after commencing clozapine, and some recovered after its discontinuation [8]; there may also have been ethnic differences [11]. Reduction of the dosage of clozapine by switching to other drugs resulted in improved glycaemic control [12]. The increased prevalence of diabetes mellitus in patients treated with clozapine has been consistently reported in epidemiological surveys [13-15], although the pathogenic mechanism of new-onset diabetes mellitus has not been established. Insulin resistance due to increased adiposity may be responsible for clozapine-induced diabetes mellitus $[16,17]$, whereas impairment of beta cell function was reported recently [18, 19]. Regarding the mechanism of beta cell dysfunction, one study showed that muscarinic receptor antagonism of clozapine impaired insulin secretion from perifused rat islets [19]. However, since muscarinic receptor blockade by itself does not cause hyperglycaemia, further studies are needed to elucidate other factors [19].

The present study was designed to investigate the effects of clozapine on glucose- and non-glucose-stimulated insulin secretion, glucose metabolism and intracellular $\mathrm{Ca}^{2+}$ concentration $\left(\left[\mathrm{Ca}^{2+}\right]_{\mathrm{i}}\right)$ in rat islets under long-term culture conditions. The results demonstrated that clozapine directly impairs glucose- and non-glucose-stimulated insulin secretion, islet glucose oxidation and $\left[\mathrm{Ca}^{2+}\right]_{\mathrm{i}}$ elevation under high glucose conditions.

\section{Materials and methods}

Islet isolation and culture

Pancreases were removed from male Sprague-Dawley rats (body weight 250-350 g; Kyudo, Kumamoto, Japan) and islets were isolated by collagenase digestion as described previously by our laboratory [20]. The islets were handpicked under a stereomicroscope (Leica MZ8; Leica, Heerbrugg, Switzerland) and transferred to RPMI 1640 medium (Sigma-Aldrich, St. Louis, MO, USA) containing $10 \%$ fetal bovine serum (Life Technologies, Grand Island, NY, USA), $100 \mathrm{U} / \mathrm{ml}$ penicillin, $100 \mu \mathrm{g} / \mathrm{ml}$ streptomycin and $11.0 \mathrm{mmol} / \mathrm{l}$ glucose in $60 \times 15-\mathrm{mm}$ Petri dishes (Sumilon, Akita, Japan). The islets (100 per dish) were cultured in $4 \mathrm{ml}$ RPMI 1640-based medium with different concentrations of clozapine (Sigma-Aldrich) in $0.1 \%$ ethanol or with the solvent alone as a control at $37^{\circ} \mathrm{C}$ in humidified air containing $5 \% \mathrm{CO}_{2}$. The culture medium was changed overnight after islet isolation and every other day thereafter. To assess islet viability in long-term cultures, 100 freshly isolated islets were cultured for 7 days with 1.0 or $5.0 \mu \mathrm{mol} / \mathrm{l}$ clozapine, which were considered to be therapeutic concentrations [21, 22] and were used in previously reported studies [19, 23]. Subsequently, all islets in the culture dish were homogenised in water, a fraction of the homogenate was analysed for DNA content (Gene Quant; Pharmacia, Cambridge, UK), and another fraction was mixed with acid ethanol for insulin extraction to determine insulin content.

All experiments were performed according to the guidelines of the animal experimentation ethics committee of Kyushu University.

Static insulin secretion

Measurements were carried out in $\mathrm{KRB}$ containing $(\mathrm{mmol} / \mathrm{l})$ : $118.4 \mathrm{NaCl}, 4.7 \mathrm{KCl}, 1.2 \mathrm{MgSO}_{4}, 1.2 \mathrm{KH}_{2} \mathrm{PO}_{4}, 2.4 \mathrm{CaCl}_{2}$ and $20 \mathrm{NaHCO}_{3}$ (equilibrated with $95 \% \mathrm{O}_{2}$ and $5 \% \mathrm{CO}_{2}$, $\mathrm{pH}$ 7.4), and supplemented with $0.2 \%$ BSA (SigmaAldrich). Islets (150-200 $\mu \mathrm{m}$ in diameter), randomly picked from the culture dish, were pre-incubated at $37^{\circ} \mathrm{C}$ for $30 \mathrm{~min}$ in $\mathrm{KRB}$ at $3.3 \mathrm{mmol} / 1$ glucose. In glucose stimulation experiments $(n=4)$, triplicate batches of five islets were incubated at $37^{\circ} \mathrm{C}$ in $0.5 \mathrm{ml} \mathrm{KRB}$ in the presence of $3.3 \mathrm{mmol} / 1$ glucose for $1 \mathrm{~h}$ under continuous shaking and then in the presence of $16.7 \mathrm{mmol} / 1$ glucose for another hour. Experiments were always performed in a parallel fashion in control and clozapine-treated islets. The reversibility of the effects of clozapine was studied 3 days after removal of the drug. In another experiment $(n=4-5)$, triplicate batches of five islets were incubated at $37^{\circ} \mathrm{C}$ in $0.5 \mathrm{ml} \mathrm{KRB}$ for $1 \mathrm{~h}$ under continuous shaking, without or with $250 \mu \mathrm{mol} / 1$ diazoxide (Sigma-Aldrich) with high $\mathrm{K}^{+}+$ KRB buffer (in mmol/l: $94.8 \mathrm{NaCl}, 28.8 \mathrm{KCl}, 1.2 \mathrm{MgSO}_{4}$, $1.2 \mathrm{KH}_{2} \mathrm{PO}_{4}, 2.4 \mathrm{CaCl}_{2}, 20 \mathrm{NaHCO}_{3}$ ). Triplicate batches of five islets were washed in $\mathrm{Ca}^{2+}$-free $\mathrm{KRB}$ buffer with $1 \mathrm{mmol} / 1$ EGTA $\left(\mathrm{Ca}^{2+}{ }^{2}\right.$ free KRB/EGTA) and then incubated at $37^{\circ} \mathrm{C}$ in $0.5 \mathrm{ml} \mathrm{Ca}{ }^{2+}$-free KRB/EGTA for $1 \mathrm{~h}$ under 
continuous shaking without or with $500 \mathrm{nmol} / 1 \mathrm{l}$ 12-Otetradecanoylphorbol-13-acetate (TPA) (Wako Biochemicals, Osaka, Japan) or $10 \mu \mathrm{mol} / \mathrm{l}$ mastoparan (Sigma-Aldrich).

In carbachol experiments $(n=4)$, islets cultured without clozapine for 3 days were used. Triplicate batches of five islets were incubated in 10 or $100 \mu \mathrm{mol} / \mathrm{l}$ carbachol at 3.3 or $7.0 \mathrm{mmol} / 1$ glucose at $37^{\circ} \mathrm{C}$ in $0.5 \mathrm{ml} \mathrm{KRB}$ for $1 \mathrm{~h}$, with $10 \mu \mathrm{mol} / 1$ atropine, and 1.0 or $5.0 \mu \mathrm{mol} / 1$ clozapine. After incubation, the medium was removed and analysed for insulin by RIA (Eiken, Tokyo, Japan), and islet DNA and insulin contents were measured as described above. Insulin secretion was expressed as $\mu \mathrm{U}$ islet ${ }^{-1} \mathrm{~h}^{-1}$ when comparing the results on the same culture day. However, when comparing results on different culture days, insulin secretion was expressed as percentage of insulin content.

Islet glucose utilisation

Islet glucose utilisation was measured by the method of Ashcroft et al. [24]. After pre-incubation in KRB at $3.3 \mathrm{mmol} / 1$ glucose for $30 \mathrm{~min}$ at $37^{\circ} \mathrm{C}$, triplicate batches of ten islets, 150 to $200 \mu \mathrm{m}$ in diameter, were placed into a 1 -ml glass cup with $16.7 \mathrm{mmol} / \mathrm{l}$ glucose and $37 \mathrm{kBq}$ d$\left[5-{ }^{3} \mathrm{H}\right]$ glucose (Amersham Pharmacia Biotech, Piscataway, $\mathrm{NJ}$, USA) in $40 \mu \mathrm{KRB}, \mathrm{pH}$ 7.4. Each cup with its content was placed in a $20-\mathrm{ml}$ glass scintillation vial containing $500 \mu \mathrm{l}$ distilled water, bubbled with $95 \% \mathrm{O}_{2}$ and $5 \% \mathrm{CO}_{2}$, and sealed airtight with a rubber stopper. The vials were shaken for $120 \mathrm{~min}$ at $37^{\circ} \mathrm{C}$. Islet glucose metabolism was stopped with $100 \mu \mathrm{l} 0.5 \mathrm{~mol} / \mathrm{HCl}$ injected through the stopper into the cup. Parallel incubations were performed without islets. ${ }^{3} \mathrm{H}_{2} \mathrm{O}$ was collected for 18 to $24 \mathrm{~h}$ at $37^{\circ} \mathrm{C}$. The cup was removed, and $5 \mathrm{ml}$ of scintillation fluid (Scintisol AL-I; Dojindo, Kumamoto, Japan) was added to the vial. After vortexing, radioactivity was counted in a liquid scintillation counter (LSC 1000; Aloka, Tokyo, Japan).

Islet glucose oxidation

After pre-incubation in $\mathrm{KRB}$ at $3.3 \mathrm{mmol} / \mathrm{l}$ glucose for $30 \mathrm{~min}$ at $37^{\circ} \mathrm{C}$, triplicate batches of ten islets, 150 to $200 \mu \mathrm{m}$ in diameter, were placed into a 1-ml glass cup with $16.7 \mathrm{mmol} / 1$ glucose and $37 \mathrm{kBq} \mathrm{d}-\left[\mathrm{U}-{ }^{14} \mathrm{C}\right]$ glucose (Amersham Pharmacia Biotech) in $100 \mu \mathrm{KRB}$, pH 7.4 [24]. Each cup with its content was placed in a $20-\mathrm{ml}$ glass scintillation vial, bubbled with $95 \% \mathrm{O}_{2}$ and $5 \% \mathrm{CO}_{2}$, and then sealed airtight with a rubber stopper. The vials were shaken for $90 \mathrm{~min}$ at $37^{\circ} \mathrm{C}$. Islet glucose metabolism was stopped with $100 \mu \mathrm{l} 0.05 \mathrm{mmol} / \mathrm{l}$ antimycin A (Wako Biochemicals) dissolved in $70 \%$ (vol/vol) ethanol, which was injected through the stopper into the cup. In the next step, $250 \mu$ l hyamine hydroxide (Packard, Meriden, CT, USA) were injected into the vial. $\mathrm{CO}_{2}$ was released from the incubation medium by injecting $100 \mu \mathrm{l} 0.4 \mathrm{~mol} / 1 \mathrm{Na}_{2} \mathrm{HPO}_{4}$ (Wako Biochemicals) solution ( $\mathrm{pH}$ 6.0) into the cup. To allow the $\mathrm{CO}_{2}$ trapping by hyamine hydroxide, the vials were shaken for another $120 \mathrm{~min}$ at $37^{\circ} \mathrm{C}$. Parallel incubations were performed without islets. The cup was removed, and $5 \mathrm{ml}$ scintillation fluid was added to the vial. After vortexing, radioactivity was counted in a liquid scintillation counter.

\section{Measurement of islet ATP contents}

ATP content was determined by a luminometric method [25]. Islets were pre-incubated in KRB at $3.3 \mathrm{mmol} / 1$ glucose at $37^{\circ} \mathrm{C}$ for $30 \mathrm{~min}$, then triplicate batches of ten islets, 150 to $200 \mu \mathrm{m}$ in diameter, were placed in $0.5 \mathrm{ml} \mathrm{KRB}$ at 3.3 or $16.7 \mathrm{mmol} / \mathrm{l}$ glucose under continuous shaking for $60 \mathrm{~min}$ at $37^{\circ} \mathrm{C}$. The reaction was stopped by adding $0.5 \mathrm{ml}$ trichloroacetic acid to a final concentration of $5 \%$. The tubes were immediately mixed with vortex and then sonicated in icecold water for $3 \mathrm{~min}$. They were centrifuged $(2,000 \mathrm{~g}$ for $3 \mathrm{~min})$, and a fraction $(0.7 \mathrm{ml})$ of the supernatant fraction was mixed with $1 \mathrm{ml}$ of water-saturated diethyl ether. The ether phase containing trichloroacetic acid was discarded. This step was repeated four times. After the extracts $(0.1 \mathrm{ml})$ were diluted with $0.1 \mathrm{ml} 20 \mathrm{mmol} / 1$ HEPES, $\mathrm{pH} 7.4$, with $\mathrm{NaOH}$, they were frozen at $-80^{\circ} \mathrm{C}$ until assays. The thawed extracts $(50 \mu \mathrm{l})$ were added to $150 \mu \mathrm{l}$ of a solution of $20 \mathrm{mmol} / \mathrm{l}$ HEPES (pH 7.75) and $3 \mathrm{mmol} / 1 \mathrm{MgCl}_{2}$. The ATP concentration in the solutions was measured by adding $100 \mu$ luciferin-luciferase solution (Enliten ATP Assay System; Promega, Madison, WI, USA) to a fraction sample $(20 \mu \mathrm{l})$ in a bioluminometer (MiniLumat LB 9506; Berthold, Bad Wildbad, Germany). To construct a standard curve, blanks and ATP standards were run through the entire procedure, including the extraction steps.

Measurement of islet $\left[\mathrm{Ca}^{2+}\right]_{\mathrm{i}}$

Measurements were carried out in KRB containing (in mmol/l): $128.8 \mathrm{NaCl}, 4.8 \mathrm{KCl}, 1.2 \mathrm{MgSO}_{4}, 1.2 \mathrm{KH}_{2} \mathrm{PO}_{4}$, $2.5 \mathrm{CaCl}_{2}, 5 \mathrm{NaHCO}_{3}$ and $10 \mathrm{HEPES}$ (KRBH; equilibrated with $\mathrm{NaOH}, \mathrm{pH} 7.4$ ), supplemented with $0.1 \%$ BSA as described previously by our laboratory [20]. Islets were attached to a glass-bottom culture dish (MatTek, Ashland, MA, USA) that had been precoated with $100 \mu \mathrm{g} / \mathrm{ml}$ poly-Llysine (Sigma-Aldrich) in RPMI 1640-based medium containing $11 \mathrm{mmol} / 1$ glucose for $1 \mathrm{~h}$ at $37^{\circ} \mathrm{C}$ in $95 \%$ $\mathrm{O}_{2}-5 \% \mathrm{CO}_{2}$ incubator. The islets were then washed twice in $\mathrm{KRBH}$ containing $2.8 \mathrm{mmol} / \mathrm{l}$ glucose, loaded with $3 \mu \mathrm{mol} / \mathrm{l}$ Fura 2/AM (Dojindo) in KRBH containing $2.8 \mathrm{mmol} / 1$ glucose, and then incubated at $37^{\circ} \mathrm{C}$ for $30 \mathrm{~min}$. The islets were placed on the stage of an inverted 


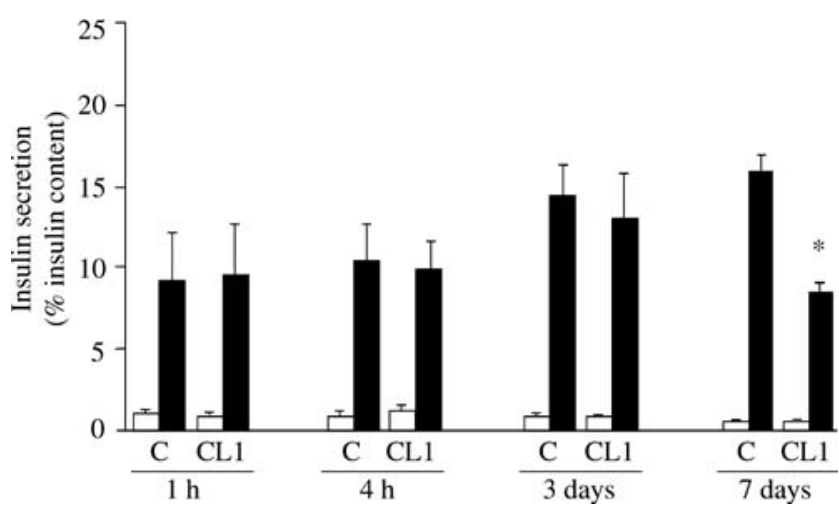

Fig. 1 Time study of the effect of $1.0 \mu \mathrm{mol} / \mathrm{l}$ clozapine (CL1) on insulin secretion at 3.3 (open bars) or 16.7 (closed bars) $\mathrm{mmol} / \mathrm{l}$ glucose. C, control. Data are mean $\pm \mathrm{SEM}$ values from four experiments. ${ }^{*} p<0.05$ vs control for same incubation time

microscope (Leica DM IRB) and superfused at $1 \mathrm{ml} / \mathrm{min}$ at $37^{\circ} \mathrm{C}$ with $\mathrm{KRBH}$ with $2.8 \mathrm{mmol} / 1$ glucose, then with $16.7 \mathrm{mmol} / 1$ glucose or $30 \mathrm{mmol} / 1 \mathrm{~K}^{+}$and 250 $\mu \mathrm{mol} / 1$ diazoxide. The Fura-2-loaded single whole islet was illuminated by excitation at $340 \mathrm{~nm}$ (F340) and $380 \mathrm{~nm}$ (F380) alternately every $8-9 \mathrm{~s}$ through a $\times 10$ fluorite objective, and the emission signals at $510 \mathrm{~nm}$ were detected by a CCD camera (C4742-95-12ER; Hamamatsu Photonics, Hamamatsu, Japan). The F340/F380 ratio image was produced using a dual excitation microfluorescence system (Aquacosmos version 1.3; Hamamatsu Photonics). The peripheral portion of the islet was omitted in the measurement, and beta cells were confirmed by applying 100 $\mu \mathrm{mol} / 1$ tolbutamide (Aventis Pharmaceuticals, Frankfurt, Germany). In each experiment, measurements were made in control and clozapine-treated islets in a parallel fashion (average number of measured islets $2.8 \pm 1.5$ [SEM]), and $\mathrm{F} 340 / \mathrm{F} 380$ ratio was used as described for $\left[\mathrm{Ca}^{2+}\right]_{\mathrm{i}}$.

\section{Statistical analysis}

Values are expressed as mean \pm SEM. Statistical significance was evaluated by unpaired or paired $t$ test, or ANOVA with Scheffe's $F$ test as a post hoc test. $P<0.05$ was considered significant.

\section{Results}

We first performed a time study of the effects of $1.0 \mu \mathrm{mol} / \mathrm{l}$ clozapine on insulin secretion at 3.3 or $16.7 \mathrm{mmol} / \mathrm{l}$ glucose (Fig. 1). Insulin secretion at $3.3 \mathrm{mmol} / \mathrm{l}$ glucose did not change up to 7 days. Insulin secretion in response to $16.7 \mathrm{mmol} / 1$ glucose did not significantly change after incubation with $1.0 \mu \mathrm{mol} / 1$ clozapine for $1 \mathrm{~h}, 4 \mathrm{~h}$ or 3 days, but was suppressed to $53.2 \pm 4.0 \%$ of the control after 7 days of incubation. Accordingly, the next series of dose studies

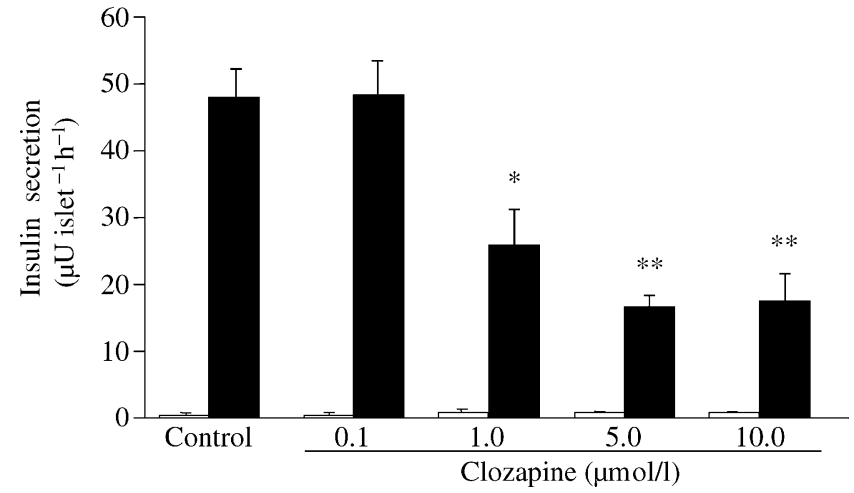

Fig. 2 Dose study at 7 days of incubation with various concentrations of clozapine. Open bars, $3.3 \mathrm{mmol} / 1$ glucose; closed bars, $16.7 \mathrm{mmol} / 1$ glucose. Data are mean \pm SEM values from four experiments for each group. ${ }^{*} p<0.05, * * p<0.01$ vs control

were performed with 7 days of incubation (Fig. 2). Basal insulin secretion at $3.3 \mathrm{mmol} / \mathrm{l}$ glucose was not affected by clozapine (up to $10.0 \mu \mathrm{mol} / \mathrm{l}$ clozapine). However, insulin secretion in response to $16.7 \mathrm{mmol} / 1$ glucose was significantly suppressed at $1.0 \mu \mathrm{mol} / 1$ clozapine, and a further reduction was seen at $5.0 \mu \mathrm{mol} / 1$ clozapine, with no additional reduction at $10.0 \mu \mathrm{mol} / \mathrm{l}$ clozapine. Since 7 days of culture with clozapine may decrease islet viability, we investigated DNA and insulin contents in all islets in dishes. Clozapine did not affect islet recovery, DNA or insulin contents after 7 days of culture (Table 1). In addition, there was no difference in DNA and insulin contents in islets extracted after the insulin secretion studies between the batches of control and clozapine-treated cells in each experiment (data not shown).

To elucidate the mechanism of impaired glucoseinduced insulin secretion, we studied islet glucose metabolism (Table 2) and changes in islet $\left[\mathrm{Ca}^{2+}\right]_{\mathrm{i}}$ by high glucose (Fig. 3) after 7 days of culture with clozapine. Islet glucose utilisation was not different between control and clozapine-treated islets, whereas islet glucose oxidation was significantly suppressed in 1.0 and $5.0 \mu \mathrm{mol} / 1$ clozapine. Islet ATP contents were not different in control and clozapine-treated islets after incubation with

Table 1 Effects of 7-day culture with clozapine on islet recovery, DNA and insulin contents

\begin{tabular}{lccll}
\hline & $n$ & Control & $\begin{array}{c}\text { Clozapine } \\
1.0 \mu \mathrm{mol} / 1\end{array}$ & $\begin{array}{c}\text { Clozapine } \\
5.0 \mu \mathrm{mol} / 1\end{array}$ \\
\hline $\begin{array}{l}\text { Islet recovery (\%) } \\
\text { DNA content } \\
(\text { ng per islet) }\end{array}$ & 3 & $71.7 \pm 4.3$ & $66.0 \pm 4.0$ & $68.0 \pm 4.0$ \\
$\begin{array}{c}\text { Insulin content } \\
(\mu \mathrm{U} \text { per islet) }\end{array}$ & 3 & $346.5 \pm 22.3$ & $378.8 \pm 45.7$ & $387.4 \pm 23.6$ \\
\hline
\end{tabular}

Values are mean $\pm \mathrm{SEM}$. 
Table 2 Effects of 7-day culture with clozapine on islet glucose metabolism and ATP production

\begin{tabular}{|c|c|c|c|c|c|}
\hline & Glucose $(\mathrm{mmol} / \mathrm{l})$ & $n$ & Control & Clozapine $1.0 \mu \mathrm{mol} / 1$ & Clozapine $5.0 \mu \mathrm{mol} / 1$ \\
\hline Islet glucose utilisation (pmol islet ${ }^{-1} 120 \mathrm{~min}^{-1}$ ) & 16.7 & 5 & $87.5 \pm 5.1$ & $82.6 \pm 9.3$ & $79.5 \pm 10.8$ \\
\hline Islet glucose oxidation (pmol islet ${ }^{-1} 90 \mathrm{~min}^{-1}$ ) & 16.7 & 5 & $32.4 \pm 4.3$ & $24.0 \pm 4.6^{\mathrm{a}}$ & $19.2 \pm 3.4^{\mathrm{a}}$ \\
\hline Islet ATP content ( $\mathrm{pmol} /$ islet)-low glucose & 3.3 & 4 & $4.7 \pm 0.3$ & $4.7 \pm 0.2$ & $4.6 \pm 0.3$ \\
\hline Islet ATP content (pmol/islet)-high glucose & 16.7 & 4 & $6.9 \pm 0.4$ & $6.3 \pm 0.6^{\mathrm{a}}$ & $5.3 \pm 0.4^{\mathrm{b}}$ \\
\hline
\end{tabular}

Values are mean \pm SEM.

${ }^{\mathrm{a}} p<0.05$ vs control. ${ }^{\mathrm{b}} p<0.01$ vs control

$3.3 \mathrm{mmol} / \mathrm{l}$ glucose, but were significantly lower in clozapine-treated islets at $16.7 \mathrm{mmol} / 1$ glucose. As depicted in Fig. 3, islet $\left[\mathrm{Ca}^{2+}\right]_{\mathrm{i}}$ in control islets increased to a peak level after the initial drop, then decreased, followed by a gradual increase. In $1.0 \mu \mathrm{mol} / 1$ clozapinetreated islets, the peak was lower than the control (ratio $1.17 \pm 0.06$ in control vs $1.10 \pm 0.08$ in $1.0 \mu \mathrm{mol} / 1$ clozapine, $p<0.01)$. In $5.0 \mu \mathrm{mol} / 1$ clozapine-treated islets, no clear peak was noted and $\left[\mathrm{Ca}^{2+}\right]_{\mathrm{i}}$ levels were consistently lower than the control. Since the reduction in islet glucose oxidation and $\left[\mathrm{Ca}^{2+}\right]_{\mathrm{i}}$ elevation seems to be responsible for impaired glucose-induced insulin secretion, we also measured islet glucose oxidation and $\left[\mathrm{Ca}^{2+}\right]_{\mathrm{i}}$ after 3 days of culture with clozapine when insulin secretion remained unaffected. Glucose oxidation rate or $\left[\mathrm{Ca}^{2+}\right]_{\mathrm{i}}$ elevation was not impaired at $16.7 \mathrm{mmol} / 1$ glucose in islets treated with clozapine for 3 days (Table 3 ).

Glucose Glucose $2.8 \mathrm{mmol} / \mathrm{l} \quad 16.7 \mathrm{mmol} / \mathrm{l}$

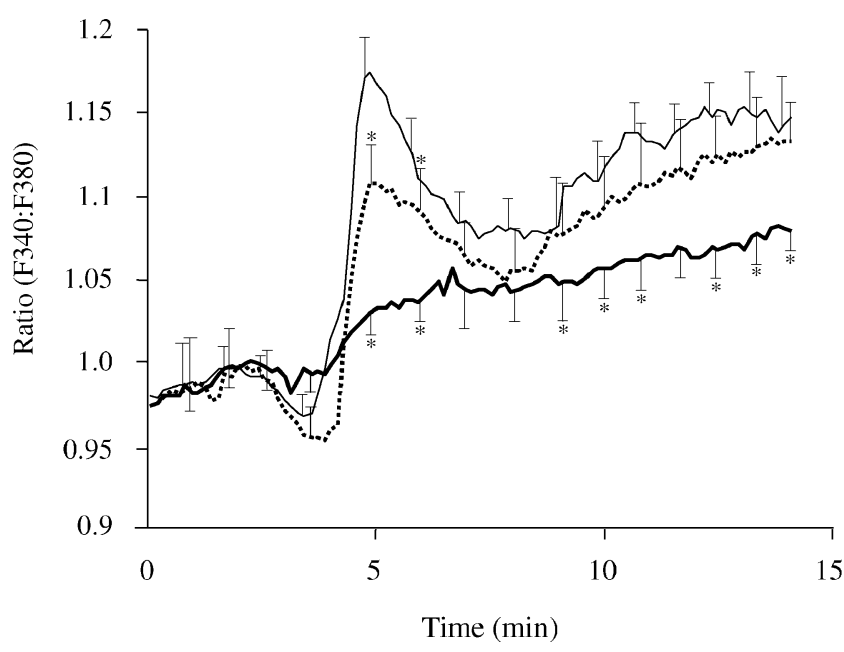

Fig. 3 Effects of 7-day culture with 1.0 or $5.0 \mu \mathrm{mol} / 1$ clozapine on islet intracellular $\mathrm{Ca}^{2+}$ concentration stimulated by $16.7 \mathrm{mmol} / 1$ glucose. Thin line, control; dotted line, $1.0 \mu \mathrm{mol} / 1$ clozapine; thick line, $5.0 \mu \mathrm{mol} / 1$ clozapine. F340, excitation of Fura-2-loaded single whole islet at $340 \mathrm{~nm} ; \mathrm{F} 380$, excitation at $380 \mathrm{~nm}$. Data are mean \pm SEM values from four experiments for each group. ${ }^{*} p<0.05$ vs control
Next, we investigated non-nutrient-stimulated insulin secretion. In 7-day cultures, insulin secretion stimulated by depolarisation with a high $\mathrm{K}^{+}$solution under diazoxide was significantly reduced in cultures treated with 1.0 and $5.0 \mu \mathrm{mol} / \mathrm{l}$ clozapine (percent of control $76.2 \pm 12.8 \%$ in $1.0 \mu \mathrm{mol} / 1$ clozapine, $p<0.05,70.2 \pm 11.7 \%$ in 5.0 $\mu \mathrm{mol} / 1$ clozapine, $p<0.01$ ) (Fig. 4). Since membrane depolarisation causes $\mathrm{Ca}^{2+}$ entry into beta cells, we measured $\left[\mathrm{Ca}^{2+}\right]_{\mathrm{i}}$ elevation induced by membrane depolarisation. As shown in Fig. 5, no significant differences were observed between control and clozapine-treated islets. Moreover, insulin secretion by protein kinase $\mathrm{C}$ (PKC) activation with TPA was significantly suppressed by 1.0 and $5.0 \mu \mathrm{mol} / \mathrm{l}$ clozapine (percent of control $82.8 \pm 15.0 \%$ in $1.0 \mu \mathrm{mol} / 1$ clozapine, $p<0.05,86.5 \pm 16.5 \%$ in $5.0 \mu \mathrm{mol} / 1$ clozapine, $p<0.05$ ) (Fig. 6), but under stringent $\mathrm{Ca}^{2+}$-free conditions, insulin secretion was suppressed only at $5.0 \mu \mathrm{mol} / \mathrm{l}$ clozapine (percent of control $64.1 \pm 10.7 \%, p<0.05$ ). Insulin secretion by mastoparan, a wasp venom that directly activates the distal exocytotic machinery [26], was unaffected by clozapine at non-stimulatory glucose concentration (Fig. 7), but was significantly suppressed by 1.0 and $5.0 \mu \mathrm{mol} / 1$ clozapine at $16.7 \mathrm{mmol} / 1$ glucose (percent of control $54.7 \pm 10.4 \%$ in $1.0 \mu \mathrm{mol} / 1$ clozapine, $p<0.05,61.7 \pm$ $14.9 \%$ in $5.0 \mu \mathrm{mol} / \mathrm{l}$ clozapine, $p<0.01)$.

Recently, Johnson et al. [19] reported that clozapine acutely inhibited acetylcholine-stimulated insulin secretion due to its muscarinic receptor antagonistic action. As shown in Fig. 8, clozapine or the muscarinic receptor antagonist, atropine, did not significantly affect insulin secretion stimulated by the acetylcholine analogue, carbachol, at $3.3 \mathrm{mmol} / 1$ glucose. However, at $7.0 \mathrm{mmol} / 1$ glucose clozapine significantly inhibited carbachol-stimulated insulin secretion as did atropine (percent of control $58.7 \pm 4.6 \%$ in $1.0 \mu \mathrm{mol} / 1$ clozapine, $p<0.01,51.0 \pm 4.0 \%$ in $5.0 \mu \mathrm{mol} / 1$ clozapine, $p<0.01,55.9 \pm 9.1 \%$ in $10 \mu \mathrm{mol} / 1$ atropine, $p<0.01)$. However, in contrast with clozapine, 7 days of culture with atropine did not affect glucose-stimulated insulin secretion (Fig. 9).

Last, we investigated the reversibility of impaired insulin secretion after 7-day incubation with clozapine (Fig. 10). At 3 days after removal of the drug, a recovery of the insulin 
Table 3 Effects of 3-day culture with clozapine on islet glucose oxidation and islet intracellular $\mathrm{Ca}^{2+}$ concentration

\begin{tabular}{lllll}
\hline & $n$ & Control & Clozapine $1.0 \mu$ mol/1 & Clozapine 5.0 $\mu$ mol/1 \\
\hline Islet glucose oxidation (pmol islet & -1 & & $\left.28 \mathrm{~min}^{-1}\right)$ \\
Islet $\left[\mathrm{Ca}^{2+}\right]_{\text {i }}$ peak ratio $(\mathrm{F} 340: \mathrm{F} 380)$ & 4 & $31.2 \pm 5.1$ & $29.8 \pm 4.1$ & $28.0 \pm 2.1$ \\
\hline
\end{tabular}

$\left[\mathrm{Ca}^{2+}\right]_{\mathrm{i}}$, intracellular $\mathrm{Ca}^{2+}$ concentration. F340, excitation of Fura-2-loaded single whole islet at $340 \mathrm{~nm}$; F380, excitation at $380 \mathrm{~nm}$. Values are mean \pm SEM.

response to $16.7 \mathrm{mmol} / \mathrm{l}$ glucose was noted, with no difference between control and clozapine-treated islets.

\section{Discussion}

Although clinical experience indicates that clozapine exerts a diabetogenic action, the mechanism of this action is not fully understood. Previous studies have indicated: (1) that $34 \%$ of 82 schizophrenic patients treated with clozapine (mean age 36 years, mean BMI $26.9 \mathrm{~kg} / \mathrm{m}^{2}$, 91\% white) developed diabetes mellitus within 5-year follow-up with weight gain not ranked as a significant risk factor for developing diabetes [27]; and (2) that insulin resistance measured by the homeostasis model assessment did not change within 2-4 months after clozapine treatment, while $55 \%$ of patients developed abnormal glucose tolerance [28]. However, insulin sensitivity evaluated by a frequently sampled intravenous glucose tolerance test was significantly reduced in schizophrenic patients treated with clozapine compared with those treated with risperidone, a newer atypical antipsychotic drug with fewer adverse metabolic effects [17]. Moreover, beta cell function tended to be impaired in clozapine-treated patients with $1.8 \mu \mathrm{mol} / \mathrm{l}$ of mean serum clozapine concentration. Since it is difficult to study the diabetogenic effects of antipsychotic drugs in

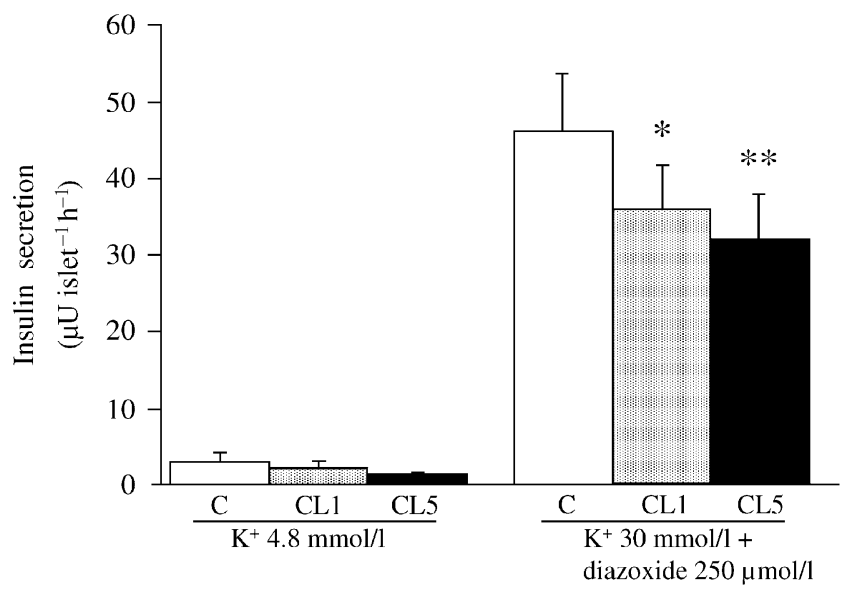

Fig. 4 Effects of 7-day culture with $1.0 \mu \mathrm{mol} / 1$ clozapine (CL1) and $5.0 \mu \mathrm{mol} / 1$ clozapine (CL5) on insulin secretion stimulated by depolarisation with high $\mathrm{K}$ solution under diazoxide. $\mathrm{C}$, control. Data are mean \pm SEM values from four experiments for each group. ${ }^{*} p<0.05, * * p<0.01$ vs control psychiatric patients due to the underlying disease, Ader et al. [18] used dogs treated with the atypical antipsychotic drugs, olanzapine and risperidone, or placebo, for 4-6 weeks. Their results showed that olanzapine markedly increased general adiposity as confirmed by magnetic resonance imaging, and caused severe hepatic insulin resistance in a euglycaemichyperinsulinaemic clamp compared with risperidone and placebo. Surprisingly, olanzapine markedly suppressed beta cell compensation for increased insulin resistance in a stepwise beta cell stimulation test. Overt type 2 diabetes usually develops when beta cell function cannot meet the increased demand for insulin secretion. Therefore, it is conceivable that the atypical antipsychotic drug may impair beta cell function, although the mechanisms involved remain to be clarified.

Johnson et al. [19] reported that acute exposure to $10 \mu \mathrm{mol} / 1$ clozapine did not affect glucose-induced insulin secretion, but did suppress carbachol-induced insulin secretion in rat pancreatic islets. Since stimulation of insulin secretion by carbachol is dependent on glucose concentration, the inhibitory effect of clozapine or atropine was not observed under non-stimulatory glucose concen-

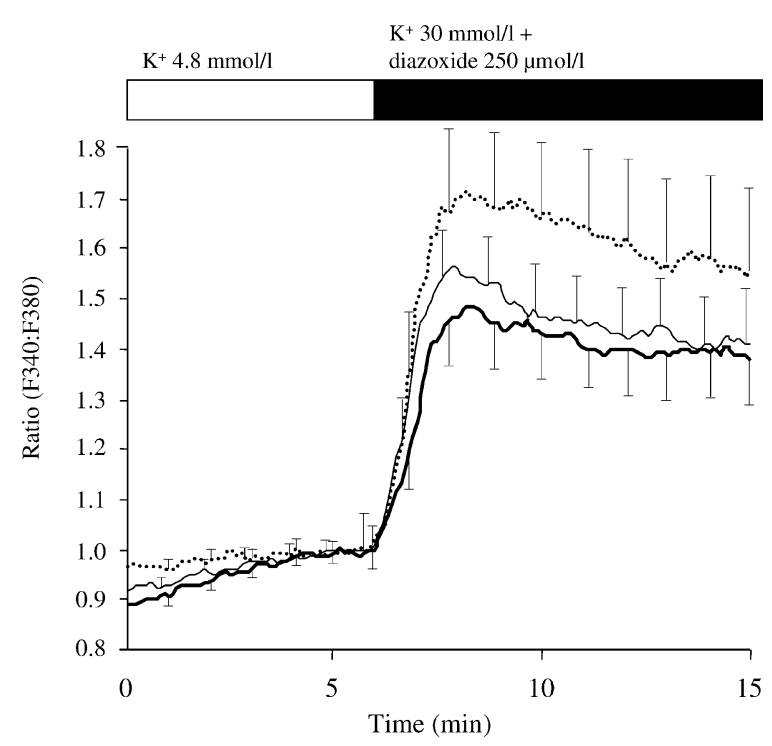

Fig. 5 Effects of 7-day culture with 1.0 or $5.0 \mu \mathrm{mol} / 1$ clozapine on islet intracellular $\mathrm{Ca}^{2+}$ concentration stimulated by depolarisation with high $\mathrm{K}^{+}$solution under diazoxide. Thin line, control; dotted line, $1.0 \mu \mathrm{mol} / 1$ clozapine; thick line, $5.0 \mu \mathrm{mol} / \mathrm{l}$ clozapine. F340, excitation of Fura-2loaded single whole islet at $340 \mathrm{~nm}$; F380, excitation at $380 \mathrm{~nm}$. Data are mean \pm SEM values from four experiments for each group 


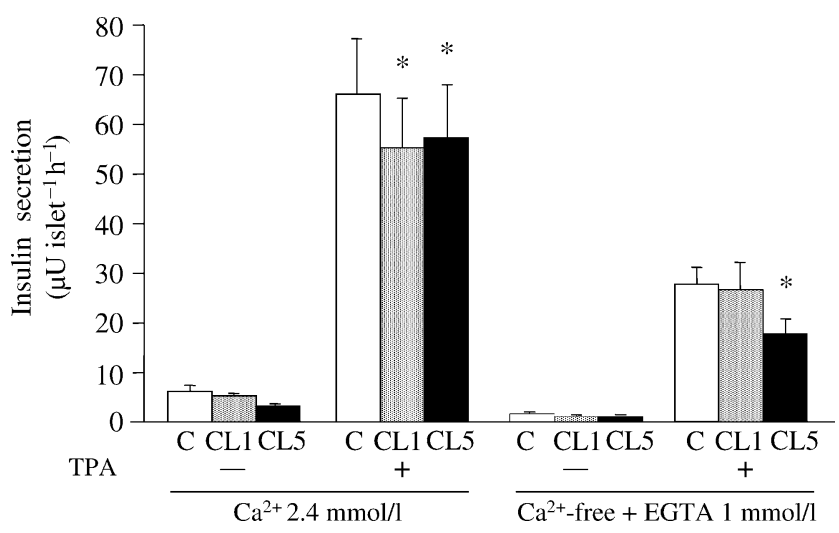

Fig. 6 Effects of 7-day culture with $1.0 \mu \mathrm{mol} / 1$ clozapine (CL1) and $5.0 \mu \mathrm{mol} / 1$ clozapine (CL5) on insulin secretion stimulated by activation of protein kinase $\mathrm{C}$ with $500 \mathrm{nmol} / 1 \mathrm{1}$ 12-O-tetradecanoylphorbol-13-acetate (TPA) under or not under stringent $\mathrm{Ca}^{2+}$-free conditions. C, control. Data are mean \pm SEM values from five experiments for each group. ${ }^{*} p<0.05$ vs control

tration, but was evident in our study at $7.0 \mathrm{mmol} / \mathrm{l}$ glucose (Fig. 8). Carbachol activates phospholipase-C and results in accumulation of inositol phosphate by binding the muscarinic $\mathrm{M}_{3}$ receptor. Johnson et al. [19] showed that clozapine had a potent muscarinic $\mathrm{M}_{3}$ receptor binding effect in vitro and suppressed inositol phosphate accumulation in islets. In the present study, however, 7 days of culture with atropine had no effects on glucose-stimulated insulin secretion in contrast with clozapine (Fig. 9). This suggests that the anticholinergic effects of clozapine in islets do not seem to contribute to the inhibitory effects of long-term culture with clozapine.

We examined the effects of long-term clozapine exposure on islet function by determining the changes in insulin secretion, islet glucose metabolism, and $\left[\mathrm{Ca}^{2+}\right]_{i}$ in islets cultured with 1.0 or $5.0 \mu \mathrm{mol} / 1$ of clozapine for 7 days. It has been reported that clozapine was metabolised by cytochrome

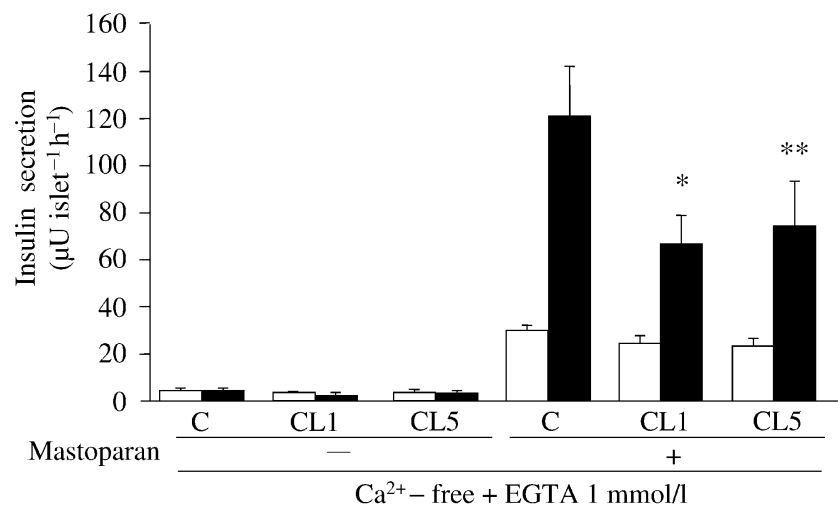

Fig. 7 Effects of 7-day culture with $1.0 \mu \mathrm{mol} / 1$ clozapine (CL1) and $5.0 \mu \mathrm{mol} / 1$ clozapine (CL5) on insulin secretion stimulated by mastoparan under stringent $\mathrm{Ca}^{2+}$-free conditions. C, control. Open bars, $3.3 \mathrm{mmol} / 1$ glucose; closed bars, $16.7 \mathrm{mmol} / 1$ glucose. Data are mean \pm SEM values from four experiments for each group. ${ }^{*} p<0.05$, $* * p<0.01$ vs control

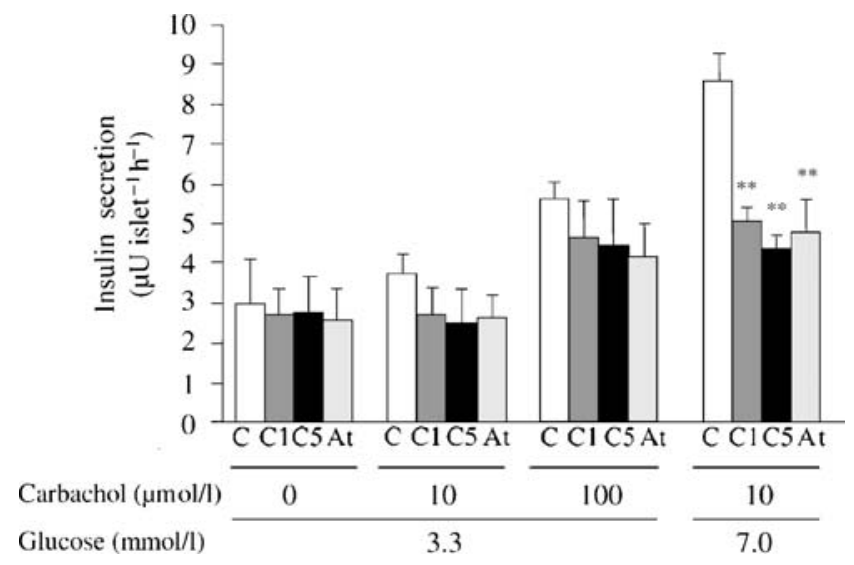

Fig. 8 Acute effects of $1.0 \mu \mathrm{mol} / 1$ clozapine (C1), $5.0 \mu \mathrm{mol} / 1$ clozapine (C5) and $10 \mu \mathrm{mol} / 1$ atropine (At) on insulin secretion stimulated by the acetylcholine analogue carbachol at 3.0 or $7.0 \mathrm{mmol} / 1$ glucose. C, control. Data are mean \pm SEM values from four experiments for each group. $* * p<0.01$ vs control

P450 in the liver, with a half-life of $7 \mathrm{~h}$ and time-to-peak concentration of $2 \mathrm{~h}$ [29]. Furthermore, the reported therapeutic plasma clozapine concentration before morning dose was $1.7 \pm 0.1 \mu \mathrm{mol} / 1$ in 162 Taiwanese patients [21] and $1.1 \pm 0.1 \mu \mathrm{mol} / 1$ in 59 patients [22]. Therefore, the clozapine concentration used in the present study was within the therapeutic ranges, and other investigators $[19,23]$ have used similar doses of clozapine to study its effect on insulin secretion in vitro. In this regard, since $94.5 \%$ of clozapine binds protein in plasma [30], the unbound clozapine concentration may be higher in culture medium due to its lower protein concentration, although the unbound concentration may vary according to tissue, e.g. the unbound clozapine concentration in cerebrospinal fluid was $26 \%$ of plasma concentration [31]. Although, due to differences in pharmacokinetics, one should be always cautious when

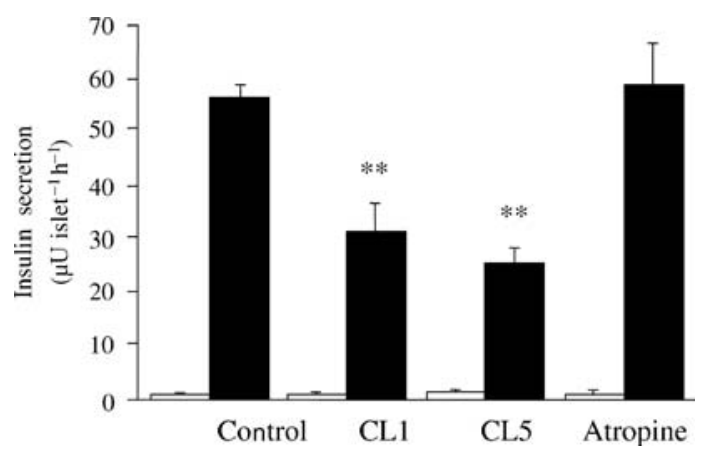

Fig. 9 Effects of 7-day culture with $1.0 \mu \mathrm{mol} / 1$ clozapine (CL1), $5.0 \mu \mathrm{mol} / 1$ clozapine (CL5) and $10 \mu \mathrm{mol} / 1$ atropine on insulin secretion at 3.3 (open bars) or 16.7 (closed bars) mmol/1 glucose. Data are mean \pm SEM values from four experiments for each group. $* * p<0.01$ vs control 


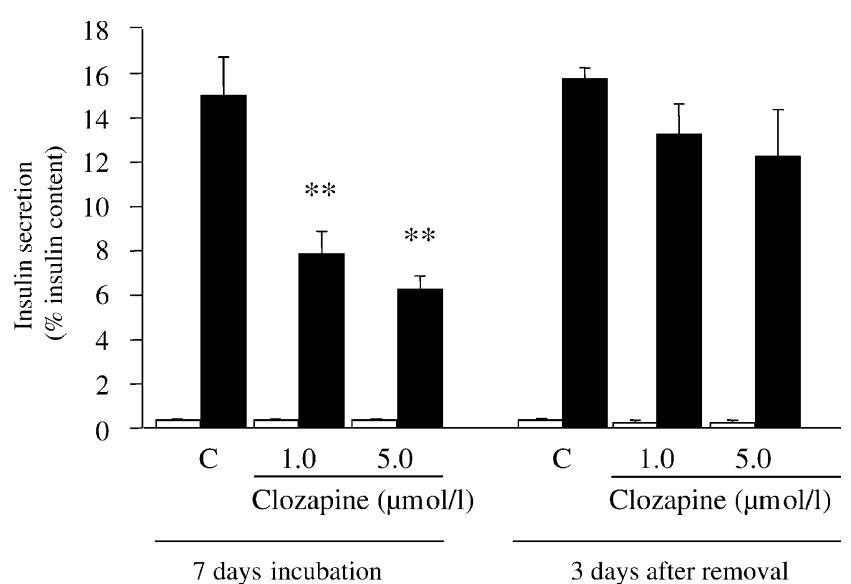

Fig. 10 Impaired insulin secretion after 7 days of incubation with clozapine, and its reversibility at 3 days after removal of clozapine. C, control. Open bars, $3.3 \mathrm{mmol} / 1$ glucose; closed bars, $16.7 \mathrm{mmol} / \mathrm{l}$ glucose. Data are mean \pm SEM values from four experiments for each group. ${ }^{* *} p<0.01$ vs control

extrapolating drug effects in vitro to in vivo, the doses used in the present study might be clinically relevant.

We demonstrated that $1.0 \mu \mathrm{mol} / \mathrm{l}$ clozapine produced $53.2 \%$ suppression of glucose-stimulated insulin secretion. Clozapine suppressed islet glucose oxidation and ATP production, and elevation of $\left[\mathrm{Ca}^{2+}\right]_{\mathrm{i}}$. The suppression of ATP production by clozapine may lead to reduced closure of ATP-sensitive $\mathrm{K}$ channels, reduction of membrane depolarisation, and reduction in the frequency of voltage-dependent $\mathrm{Ca}^{2+}$ channel opening. Consequently, the elevation in $\left[\mathrm{Ca}^{2+}\right]_{\mathrm{i}}$ that triggers insulin secretion was suppressed. Glucose oxidation or $\left[\mathrm{Ca}^{2+}\right]_{i}$ elevation was not different in control and clozapine-treated islets after 3 days when insulin secretion was unaffected by clozapine. This suggests that impaired glucose oxidation plays a role in the pathogenesis of beta cell dysfunction. The decreased glucose oxidation with unchanged glucose utilisation indicates impairment of the tricarboxylic acid (TCA) cycle in the mitochondria, although we did not study how clozapine inhibits enzymes of the TCA cycle. It has been reported that clozapine inhibited complex I in the respiratory chain of rat brain mitochondria at $100 \mu \mathrm{mol} / \mathrm{l}$ [32], and that, at pharmacological concentrations, it suppressed glucose transport in rat pheochromocytoma cells with a half-maximal inhibitory concentration $\left(\mathrm{IC}_{50}\right)$ of $20 \mu \mathrm{mol} / 1$ [33]; it also inhibited activation of voltage-dependent $\mathrm{Ca}^{2+}$ channels with $\mathrm{IC}_{50}$ of $55 \mu \mathrm{mol} / \mathrm{l}$ in bovine adrenal chromaffin cells [34].

Regarding non-fuel-stimulated insulin secretion, clozapine suppressed insulin secretion by high $\mathrm{K}^{+}$-induced membrane depolarisation without affecting elevation of $\left[\mathrm{Ca}^{2+}\right]_{\mathrm{i}}$, suggesting impairment of distal steps of the insulin exocytosis process. In addition, clozapine significantly suppressed insulin secretion stimulated by TPA-sensitive PKC, although no effect was seen at $1.0 \mu \mathrm{mol} / \mathrm{l}$ clozapine under
$\mathrm{Ca}^{2+}$-free conditions. It has been reported that PKC plays a role as amplifier of the triggering signals to release insulin, possibly at the vesicle transport step [35]. Mastoparan, a tetradecapeptide from wasp venom, stimulated insulin release under stringent $\mathrm{Ca}^{2+}$-free conditions, possibly by activating the Rho subfamily of small GTP-binding proteins $[36,37]$. In the present study, clozapine did not affect mastoparan-induced insulin secretion at $3.3 \mathrm{mmol} / \mathrm{l}$ glucose, but did suppress its augmentation of glucose in a $\mathrm{Ca}^{2+}$ independent manner. Glucose augments posttranslational modifications of specific small G proteins in a GTP-sensitive manner [38, 39], and glucose augmentation is extremely dependent on GTP, which increases in parallel with ATP on glucose stimulation [40]. Therefore, clozapine may affect the activation of a specific $G$ protein by inhibiting ATP production, and this could contribute, at least in part, to the alteration in distal steps of insulin secretion. In the present study, membrane depolarisation by high $\mathrm{K}^{+}$normally increased $\left[\mathrm{Ca}^{2+}\right]_{\mathrm{i}}$ in clozapine-treated islets, whereas clozapine attenuated $\left[\mathrm{Ca}^{2+}\right]_{\mathrm{i}}$ elevation induced by high glucose by inhibiting glucose metabolism and ATP production. Since clozapine did not induce a generalised loss of insulin secretion or insulin contents, the effects of clozapine do not seem to be non-specific.

In conclusion, clozapine inhibited glucose- and nonnutrient-stimulated insulin secretion in rat islets at 7 days of culture. Clozapin also inhibited glucose oxidation, ATP production and $\left[\mathrm{Ca}^{2+}\right]_{\mathrm{i}}$ elevation. In addition, it inhibited the distal step in insulin exocytosis, although the impairment of insulin secretion was not generalised. We showed an anti-cholinergic effect of clozapine on insulin secretion, but this effect does not seem to contribute to impaired insulin secretion in response to glucose or non-nutrient secretagogues in islets chronically exposed to clozapine. The present study demonstrated that the atypical antipsychotic drug clozapine directly impairs insulin secretion via different mechanisms at multiple sites, i.e. impairment of islet glucose oxidation and distal step insulin exocytosis. However, the beta cell dysfunction induced by clozapine seems reversible upon withdrawal, as shown in Fig. 8-a finding compatible with reported clinical experience [8].

Duality of interest We declare that we have no duality of interest.

\section{References}

1. Freedman R (2003) Schizophrenia. N Engl J Med 349:1738-1749

2. Kane J, Honigfeld G, Singer J, Meltzer H (1988) Clozapine for the treatment-resistant schizophrenic. A double-blind comparison with chlorpromazine. Arch Gen Psychiatry 45:789-796

3. Meltzer HY, Okayli G (1995) Reduction of suicidality during clozapine treatment of neuroleptic-resistant schizophrenia: impact on risk-benefit assessment. Am J Psychiatry 152:183-190 
4. McEvoy JP, Freudenreich O, Wilson WH (1999) Smoking and therapeutic response to clozapine in patients with schizophrenia. Biol Psychiatry 46:125-129

5. Idanpaan-Heikkila J, Alhava E, Olkinuora M, Palva I (1975) Clozapine and agranulocytosis (letter). Lancet ii:611

6. Holt RI, Peveler RC, Byrne CD (2004) Schizophrenia, the metabolic syndrome and diabetes. Diabet Med 21:515-523

7. Koval MS, Rames LJ, Christie S (1994) Diabetic ketoacidosis associated with clozapine treatment. Am J Psychiatry 151:1520-1521

8. Koller E, Schneider B, Bennett K, Dubitsky G (2001) Clozapineassociated diabetes. Am J Med 111:716-723

9. Jin H, Meyer JM, Jeste DV (2002) Phenomenology of and risk factors for new-onset diabetes mellitus and diabetic ketoacidosis associated with atypical antipsychotics: an analysis of 45 published cases. Ann Clin Psychiatry 14:59-64

10. Ananth J, Venkatesh R, Burgoyne K, Gunatilake S (2002) Atypical antipsychotic drug use and diabetes. Psychother Psychosom 71:244-254

11. Cohen D (2004) Atypical antipsychotics and new onset diabetes mellitus. An overview of the literature. Pharmacopsychiatry 37:1-11

12. Reinstein MJ, Sirotovskaya LA, Jones RE, Mohan S, Chasanov MA (1999) Effect of clozapine-quetiapine combination therapy on weight and glycaemic control. Clin Drug Investig 18:99-104

13. Sernyak MJ, Leslie DL, Alarcon RD, Losonczy MF, Rosenheck R (2002) Association of diabetes mellitus with use of atypical neuroleptics in the treatment of schizophrenia. Am J Psychiatry 159:561-566

14. Hedenmalm K, Hagg S, Stahl M, Mortimer O, Spigset O (2002) Glucose intolerance with atypical antipsychotics. Drug Safety 25:1107-1116

15. Gianfrancesco FD, Grogg AL, Mahmoud RA, Wang RH, Nasrallah HA (2002) Differential effects of risperidone, olanzapine, clozapine, and conventional antipsychotics on type 2 diabetes: findings from a large health plan database. J Clin Psychiatry 63:920-930

16. Lean ME, Pajonk FG (2003) Patients on atypical antipsychotic drugs another high-risk group for type 2 diabetes. Diabetes Care 26:1597-1605

17. Henderson DC, Cagliero E, Copeland PM et al (2005) Glucose metabolism in patients with schizophrenia treated with atypical antipsychotic agents: a frequently sampled intravenous glucose tolerance test and minimal model analysis. Arch Gen Psychiatry 62:19-28

18. Ader M, Kim SP, Catalano KJ et al (2005) Metabolic dysregulation with atypical antipsychotics occurs in the absence of underlying disease a placebo-controlled study of olanzapine and risperidone in dogs. Diabetes 54:862-871

19. Johnson DE, Yamazaki H, Ward KM et al (2005) Inhibitory effects of antipsychotics on carbachol-enhanced insulin secretion from perifused rat islets: role of muscarinic antagonism in antipsychotic-induced diabetes and hyperglycemia. Diabetes 54:1552-1558

20. Uchizono Y, Iwase M, Nakamura U, Sasaki N, Goto D, Iida M (2004) Tacrolimus impairment of insulin secretion in isolated rat islets occurs at multiple distal sites in stimulus-secretion coupling. Endocrinology 145:2264-2272

21. Chang WH, Lin SK, Lane HY, Hu WH, Jann MW, Lin HN (1997) Clozapine dosages and plasma drug concentrations. J Formos Med Assoc 96:599-605

22. Hasegawa M, Gutierrez-Esteinou R, Way L, Meltzer HY (1993) Relationship between clinical efficacy and clozapine concentrations in plasma in schizophrenia: effect of smoking. J Clin Psychopharmacol 13:383-390
23. Melkersson K, Khan A, Hilding A, Hulting AL (2001) Different effects of antipsychotic drugs on insulin release in vitro. Eur Neuropsychopharmacol 11:327-332

24. Ashcroft SJ, Weerasinghe LC, Bassett JM, Randle PJ (1972) The pentose cycle and insulin release in mouse pancreatic islets. Biochem J 126:525-532

25. Hampp R (1985) Luminometric method. In: Bergmeyer HU (ed) Methods of enzymatic analysis. Verlagsgesellschaft, Weinheim, pp 370-379

26. Komatsu M, McDermott AM, Gillison SL, Sharp GW (1993) Mastoparan stimulates exocytosis at a $\mathrm{Ca}(2+)$-independent late site in stimulus-secretion coupling. Studies with the RINm5F beta-cell line. J Biol Chem 268:23297-23306

27. Henderson DC, Cagliero E, Gray C et al (2000) Clozapine, diabetes mellitus, weight gain, and lipid abnormalities. A five-year naturalistic study. Am J Psychiatr 157:975-981

28. Howes OD, Bhatnagar A, Gaughran FP, Amiel SA, Murray RM, Pilowsky LS (2004) A prospective study of impairment in glucose control caused by clozapine without changes in insulin resistance. Am J Psychiatr 161:361-363

29. Tassaneeyakul W, Kittiwattanagul K, Vannaprasaht S et al (2005) Steady-state bioequivalence study of clozapine tablet in schizophrenic patients. J Pharm Pharm Sci 8:47-53

30. Schaber G, Stevens I, Gaertner HJ, Dietz K, Breyer-Pfaff U (1998) Pharmacokinetics of clozapine and its metabolites in psychiatric patients: plasma protein binding and renal clearance. Br J Clin Pharmacol 46:453-459

31. Nordin C, Alme B, Bondesson U (1995) CSF and serum concentrations of clozapine and its demethyl metabolite: a pilot study. Psychopharmacology 122:104-107

32. Burkhardt C, Kelly JP, Lim YH, Filley CM, Parker WD Jr (1993) Neuroleptic medications inhibit complex I of the electron transport chain. Ann Neurol 33:512-517

33. Ardizzone TD, Bradley RJ, Freeman AM 3rd, Dwyer DS (2001) Inhibition of glucose transport in $\mathrm{PC} 12$ cells by the atypical antipsychotic drugs risperidone and clozapine, and structural analogs of clozapine. Brain Res 923:82-90

34. Park TJ, Seo HK, Kang BJ, Kim KT (2001) Noncompetitive inhibition by camphor of nicotinic acetylcholine receptors. Biochem Pharmacol 61:787-793

35. Henquin JC (2000) Cell biology of insulin secretion. In: Kahn CR, Weir GC, King GL, Jacobson AM, Moses AC, Smith RJ (eds) Joslin's diabetes mellitus, 14th edn. Lippincott, Williams \& Wilkins, Philadelphia, pp 83-107

36. Daniel S, Noda M, Cerione RA, Sharp GW (2002) A link between $\mathrm{Cdc} 42$ and syntaxin is involved in mastoparan-stimulated insulin release. Biochemistry 41:9663-9671

37. Amin RH, Chen HQ, Veluthakal R et al (2003) Mastoparaninduced insulin secretion from insulin-secreting betaTC3 and INS1 cells: evidence for its regulation by Rho subfamily of $G$ proteins. Endocrinology 144:4508-4518

38. Kowluru A, Seavey SE, Li G et al (1996) Glucose- and GTPdependent stimulation of the carboxyl methylation of CDC42 in rodent and human pancreatic islets and pure beta cells. Evidence for an essential role of GTP-binding proteins in nutrient-induced insulin secretion. J Clin Invest 98:540-555

39. Amin R, Chen HQ, Tannous M, Gibbs R, Kowluru A (2002) Inhibition of glucose- and calcium-induced insulin secretion from betaTC3 cells by novel inhibitors of protein isoprenylation. J Pharmacol Exp Ther 303:82-88

40. Straub SG, James RF, Dunne MJ, Sharp GW (1998) Glucose augmentation of mastoparan-stimulated insulin secretion in rat and human pancreatic islets. Diabetes 47:1053-1057 